\title{
Examining the State of Public-Private Partnership (PPP) Institutionalization in the United States
}

\author{
Carter B. Casady ${ }^{1 *}$, Kent Eriksson ${ }^{2}$, Raymond E. Levitt ${ }^{3}$, and W. Richard Scott ${ }^{4}$
}

\begin{abstract}
Globally, public-private partnerships (PPPs) have increased in popularity as an alternative procurement model for infrastructure development projects. While PPPs have been widely researched and remain subject to extensive debate, the process of PPP institutionalization has been largely overlooked. To address this knowledge gap, we utilize a combination of both Johnson et al.'s (2006) four phases of institutionalization - innovation, local validation, diffusion, and general validation - and Mrak's (2014) three models of PPP institutionalization-centralized, decentralized, and mixed - to examine the current state of the U.S. PPP market. Using data on 368 U.S. PPP projects from Inframation's global transactions database, our case analysis indicates America's PPP institutionalization process is strongly decentralized and currently in a state of diffusion. Our analysis also suggests general validation of PPPs in the U.S. will likely be predicated on shifting to a mixed PPP institutionalization model.
\end{abstract}

\section{Keywords}

Institutionalization, governance, public-private partnerships (PPPs), infrastructure, United States

${ }^{1} \mathrm{PhD}$ Candidate, Department of Civil and Environmental Engineering, Stanford University, USA, +1 (310) 592-8163, cbcasady@stanford.edu.*Corresponding author

2 Professor, School of Architecture and the Built Environment, KTH Royal Institute of Technology, Sweden, Phone +08-7907309, kent.eriksson@abe.kth.se. Abo Akademi University, Turku, Finland

${ }^{3}$ Professor Emeritus, Department of Civil and Environmental Engineering, Stanford University, USA, rel@stanford.edu

${ }^{4}$ Professor Emeritus, Department of Sociology, Stanford University, USA, scottwr@stanford.edu 
$(2014,92)$ points out that "[e]xperience from other

\section{Introduction}

Around the world, public-private partnerships (PPPs) have been widely touted for their ability to overcome shortcomings in traditional infrastructure procurement. However, these agreements also create many unique governance issues for public agencies (Guasch, Laffont, and Straub 2008; Mahalingam 2010; Garvin 2010; Delhi and Mahalingam 2017). By their nature, PPPs force governments to engage private firms in complex, co-dependent relationships, networks, and exchanges throughout the lifecycle of public infrastructure assets (Grimsey and Lewis 2007; Yescombe 2011; South, Levitt, and Dewulf 2015). One of the longstanding concerns associated with these types of long-term contracts is the resulting loss of government flexibility (Ross and Yan 2015). Additionally, PPPs as a procurement model exhibit high transaction costs and long tendering periods (KPMG 2010; Reeves, Palcic, Flannery, and Geddes 2017). Moreover, PPPs may not always provide the public sector and taxpayers with adequate value for money (VfM) (HM Treasury 2012; Burger and Hawkesworth 2011). In some cases, PPPs can even create budgetary problems (Hellowell and Vecchi 2015). If governments lack the capacity to engage private firms in these complex, networked environments, successful planning, execution, and stewardship of PPPs becomes especially challenging (Geddes and Reeves 2017).

PPPs thus require proper safeguards (Buxbaum and Ortiz 2007), strong political commitment (Greve and Hodge 2010), "aggressive management by a strong, competent government" (Kettl 2011, 6 ), and well-designed governance mechanisms (OECD 2015) in order to ensure "public services are not compromised for the sake of private profits" (Forrer et. al. 2007, 477). Although successful PPP stewardship has been attributed to a variety of different factors (see, e.g. Hodge and Greve 2005; Grimsey and Lewis 2007; Kwak et al. 2009), many scholars generally agree mature PPP programs depend on one critical factor: a strong institutional setting (see, e.g. Jooste et al. 2011, Martin et al. 2013; Matos-Castaño et al. 2014, Chou and Pramudawardhani 2015; Opara et al. 2017). Mrak countries clearly indicates that creating effective institutional support is of key importance for initiating and developing the PPP concept in a country." In leading PPP jurisdictions, such as Australia, Canada, and the United Kingdom, as well as other countries across Europe, Asia, and Latin America, elaborate institutional structures, economic policies, and social norms have emerged to support the use of PPPs. Farquharson et al. (2011) note that many of these mature settings have:

(1) Clear policy rationales for PPPs;

(2) Streamlined PPP legislation;

(3) Transparent approval processes;

(4) Robust project pipelines;

(5) Consistent frameworks for project selection, preparation, and procurement;

(6) Standardized commercial contracts;

(7) Clear dispute resolution procedures; and

(8) Multiple PPP units managing bid preparation, solicitation, and evaluation.

While these features may be commonplace within many well-developed PPP jurisdictions, "institutional change ... is path-dependent and is a function of a variety of context-specific variables[,]" meaning "[t]here is no one-size-fitsall institutional framework that is universally applicable for the pursuit of PPPs" (Matos-Castaño et al. 2014, 48). Moreover, because institutional change is path-dependent, institutionalization is not deterministic. Markets can mature and regress due to changes in the institutional setting. As a result, countries around the world use a wide variety of PPP approaches and most lack national PPP models (Hodge 2013; Siemiatycki 2013; Van den Hurk et al. 2015).

Recent research examining the development of PPP institutional settings have sought to understand these cross-national differences and development trends. To date, only a handful of studies have examined the impact of institutional, political, and government support structures on PPP market development and performance (see, 
validation - and Mrak's (2014) three models of PPP institutionalization-centralized, decentralized, and mixed - to examine the current state of the U.S. PPP market. Finally, we conclude by summarizing our contributions and their implications for further research. participation rights, and transparency within PPPs along six dimensions-risk, costs and benefits, political and social impacts, expertise, collaboration, and performance measurement - in order to avoid instances of corruption and regulatory capture. Wibowo and Alfen (2015) have also documented 30 government-led critical success factors (CSFs) for PPP infrastructure development. Likewise, Delhi and Mahalingam (2017) recently identified 19 dimensions influencing PPP institutional environments and project characteristics, 13 strategic governance mechanisms that impact post-award PPP outcomes, and 7 outcome dimensions-financial sustainability, adaptability, legitimacy, the extent of restructuring, sustained performance, conformance to budget and conformance to schedule - that can be used to assess post-award PPP performance, predict post-award outcomes, and design projects for optimal governance across the lifecycle.

While many of these studies highlight conditions which are critical to PPP market development, relatively little attention has been given to the process by which countries institutionalize the PPP model. This papers, thus, builds on these extant studies of PPP institutional environments by exploring the process of PPP institutionalization in the United States. By examining the process in which PPPs "emerge, diffuse, and become legitimated over time" (Lawrence, Winn, and Jennings 2001 , 624), we intend to show "that institutional support or the lack of it is one of the key factors that defines a country's success or failure in establishing an active PPP program" (Mrak 2014, 93). In the following section, we begin with a brief overview of PPPs, the concept of PPP institutionalization, and the research questions we attempt to answer in our exploratory analysis of the U.S. PPP market. Next, we outline our research design and methodology. Then, we utilize a combination of Johnson et al.'s (2006) four phases of institutionalizationinnovation, local validation, diffusion, and general

\section{Public-Private Partnerships and the Institutionalization Process: An Overview}

Public-private partnerships (PPPs) are not new (Wettenhall 2003, 2005; Bovaird 2004; Hodge and Greve 2007). According to Kettl $(1993,4)$ :

Every major policy initiative launched by the [U.S.] federal government since World War II-including Medicare and Medicaid, environmental cleanup and restoration, antipoverty programs and job training, interstate highways and sewage treatment plants and even security in post-conflict zones-has been managed through publicprivate partnerships.

However, long-term infrastructure PPP contracts emerged as a popular mechanism for governments to engage private firms in infrastructure project delivery following the U.K.'s Private Finance Initiative (PFI) during the early 1990s. Since then, the U.S. and governments around the world haven been increasingly incorporating private-sector expertise, resources, and risk management proficiency into infrastructure project delivery through the use of PPPs. Although PPPs do not have a uniform meaning (Marsilio, Cappellaro, and Cuccurullo 2011), these contracts generally bundle various infrastructure project phases, including facility design, construction, financing, operations, and maintenance, into long-term contracts with private consortiums. These contractual arrangements typically involve a significant transfer of risks from the public-sector project sponsor to private, thirdparty actors and link remuneration to performance of the contracted service (Casady and Geddes 2016; World Bank 2017). Together, these two unique features of PPPs-bundling phases and 
Figure 1: General Spectrum of PPP Model Types

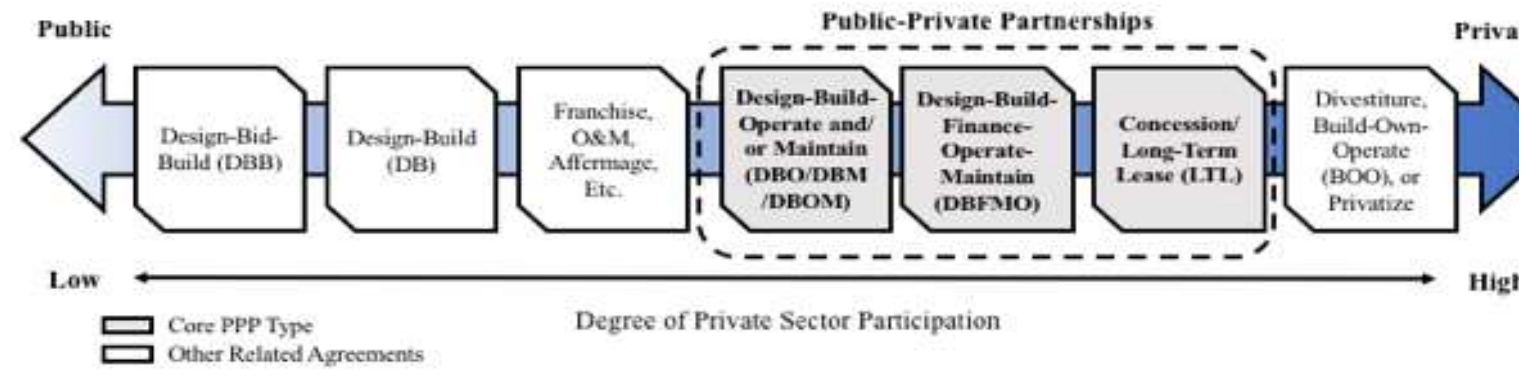

taxpayer/private partner risk sharing-allow governments to holistically address multiple stages of the project lifecycle without developing the technical, financial, and physical resources needed to deliver and maintain these projects themselves. Depending on how public agencies construct these innovative procurement agreements, PPPs can take on a wide range of structures (see Figure 1).

Across the PPP spectrum, governments must balance trade-offs between contractual incentives, project flexibility, and institutional dynamism (Bennett and Iossa 2006; Martimort and Pouyet 2008; Iossa and Martimort 2015). When appropriately planned, executed, and managed, PPPs can deliver benefits such as on-time and within-budget delivery, enhanced technological implementation, access to new forms of capital, novel financing solutions, design innovation, optimized risk sharing, life cycle costing, and faster project development (Hodge and Greve 2007; Raisbeck, Duffield, and Xu 2010; Hodge, Greve, and Boardman 2010; Lammam et al. 2013; Engel, Fischer, and Galetovic 2014; Casady and Geddes 2016).

\section{Defining PPP Institutionalization}

In order for countries to realize the benefits of PPPs, governments must undergo a process of "PPP institutionalization." According to Mrak (2014: 93-94):

The term "PPP institutionalization" can be understood to mean the formation of a standardized PPP model promoted by a central or regional government and carried out in the form of a broad spectrum of activities at various levels of decisionmaking and in various public sector bodies.

In markets where PPP institutionalization is successful, strong institutional platforms help shape and deliver policy, prepare and procure projects, and manage/regulate project agreements (Farquharson et al. 2011). These institutional settings generally mature over time through an ongoing structuration of organizational fields (Scott and Meyer 1994). Organization fields, typically, are defined around a specific type of organization - in this case, a PPP project — but also include other types of organizations that importantly relate to this organization by providing resources, consuming services, expressing opposition, or providing oversight. Field "structuration" refers to the processes by which arenas of social activity are ordered. As this process proceeds, organizations engage in increased interaction, are increasingly interdependent, and exhibit greater consensus on appropriate organizational forms and procedures for doing work (DiMaggio and Powell 1983). Mature fields also exhibit higher levels of legitimacy based on "generalized perception[s] or assumption[s] that the actions of [entities involved in PPP projects] are desirable, proper or appropriate within some socially constructed system of norms, values, beliefs and definitions" (Suchman 1995b, 574). In PPP markets, this maturation process typically relies on broad facilitating factors such as "market potential, institutional guarantees, government credibility, financial accessibility, government capacity, consolidated management, and corruption control" 
(Yang, Hou, and Wang 2013, 301). These factors, coupled with local geography, political conditions, and capital market sophistication, drive the viable formation of partnerships (Eggers and Startup 2006). Moreover, regulative and normative interactions, characterized by legislation, agency development, and legal precedents, further underpin PPP-enabling institutions by clarifying responsibilities, interfaces, procedures, and processes both within and between market actors and the public sector. Taken together, these significant institutional and strategic elements influence the adoption, maturation, and legitimation of PPP markets.

\section{The U.S. PPP Market: A Unique Case}

Not surprisingly, governments around the world have responded to the PPP institutionalization process in very different ways (Petersen 2011). While some countries have eagerly embraced PPPs and developed extensive PPP programs, others have remained skeptical of the PPP model (Verhoest et al. 2013). The United States is one of the latter countries where institutional capacity for PPPs remains relatively underdeveloped. Although the United States has historically embraced private sector involvement in the provision of other government services (see e.g. Moulton and Anheier 2002; Kinder 2012), its current infrastructure PPP market remains relatively nascent (McNichol 2013, Casady and Geddes 2016). This is because:

[U.S.] public procurement authorities often fail to appreciate the significant differences between PPPs and traditional forms of procurement and the implication of these differences for the level of resources, the unique skills, the output-based nature of the contracts, and the new processes and institutions required (Farquharson et al. 2011, 23).

Moreover, PPP institutionalization in the U.S. is often inhibited by public sector fragmentation, a

${ }^{1}$ While Buckberg, Mudge, and Sheffield (2018) do not examine PPP institutionalization explicitly, they do conflicted and inconsistent political setting, lack of project preparation capacity, and insufficient trust in the private sector to properly design and structure PPP projects (Mahalingam 2010). In spite of these observations within America's unique institutional setting, there is currently no detailed study analyzing the institutionalization of PPPs in the United States. ${ }^{1}$ Thus, the aim of this paper is to explore the U.S. PPP institutionalization process and address the following research questions:

(1) At what stage in the institutionalization process is the U.S. PPP market?

(2) What model of PPP institutionalization is the United States experiencing?

\section{Research Design and Methodology}

To answer these research questions, we use a theory-building, case-based research design (Eisenhardt and Graebner 2007). Commonly used in evaluations, this case study method was selected because our research addresses descriptive questions and draws on theoretical propositions of institutionalization (Yin 2017). More specifically, our approach utilizes two different theoretical frameworks of institutionalization in order to analyze the U.S. PPP market as a single, holistic case.

\section{Framework \#1: Stages of PPP Institutionalization}

The first theory we employ is Johnson et al.'s (2006) four phases of institutionalizationinnovation, local validation, diffusion, and general validation. In typical institutionalization processes, "[innovations] are first recognized, then accepted by relatively few actors, and then widely diffused and broadly accepted within a field" (Lawrence, Winn, and Jennings 2001, 626; see also, e.g. Meyer and Rowan 1977; Zucker 1987; Suchman 1995a; Hall and Scott 2018). Together, these phases form a temporal pattern, known as an "instance of

provide a detailed overview of recent trends in the U.S. PPP market. 
Figure 2: Traditional Institutionalization Curve

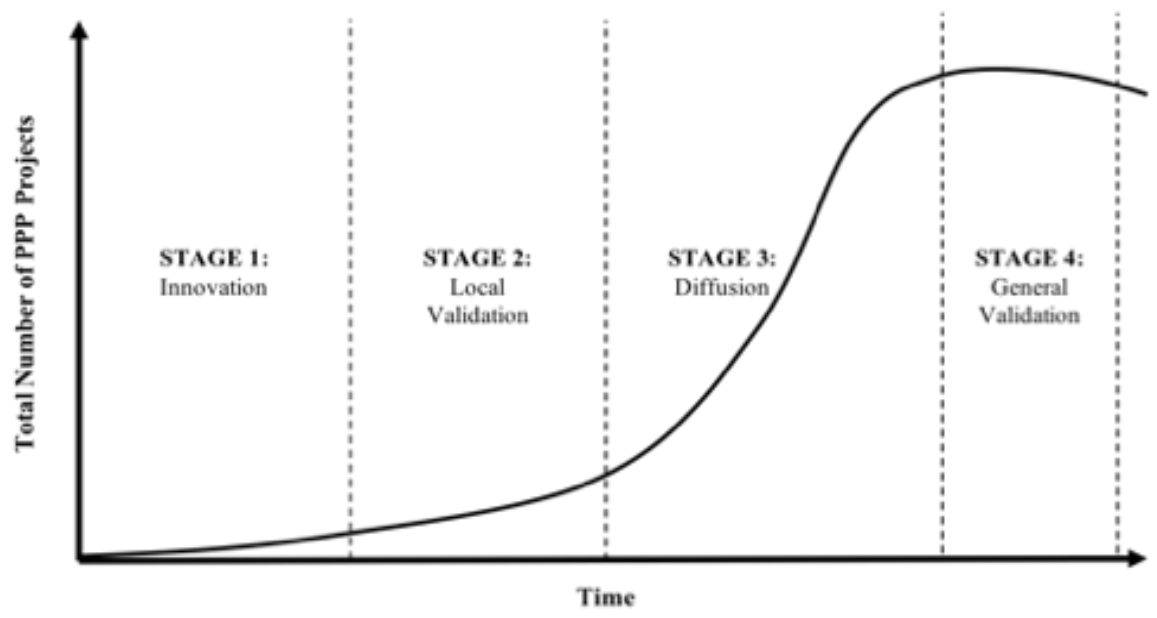

institutionalization" (Lawrence, Winn, and Jennings 2001). Figure 2 exhibits a traditional, Sshaped institutionalization curve.

While "no one precise shape of curve [and length of stage] fits the dynamics associated with all instances of institutionalization" (Lawrence, Winn, and Jennings 2001, 627), this model represents a typically pattern of more successful innovations. In the context of PPPs, the four phases of institutionalization are defined as follows:

(1) Innovation - the emergence of PPPs as an innovative procurement mechanism to deliver infrastructure assets;

(2) Local Validation - the utilization of PPPs in specific, localized settings ${ }^{2}$;

(3) Diffusion - the proliferation of PPPs in other contexts; and

(4) General Validation - the widespread acceptance, utilization, and effective governance of PPPs in infrastructure project delivery.
Using these phases of institutionalization, we attempt to isolate America's current stage in the PPP institutionalization process.

\section{Framework \#2: Models of PPP Institutionalization}

Within these transitory stages, we also attempt to classify the type of PPP institutionalization the United States is experiencing. The type of PPP institutionalization a country experiences typically depends on the creation of specialized PPP units or task forces within the government. These organizations retain "[r]esponsibility for the development and promotion of the standardized [PPP] model" (Mrak 2014, 94) and are designed to provide PPP policy guidance, program support, project-delivery approval, and quality control (EPEC 2014). Within these areas, PPP units generally engage in tasks such as project scoping, business case development, market sounding, bid evaluation, and contract enforcement (Istrate and Puentes 2011; Casady and Geddes 2016). In many cases, PPP units also have "a lasting mandate to manage multiple PPP transactions, often in multiple sectors" and "[ensure] that PPPs meet specific quality criteria such as affordability, value-

2 This could include specific jurisdictions or isolated sectors. 
for-money (VfM), and appropriate risk transfer" (World Bank 2007, 2).

Governments undergoing PPP institutionalization commonly establish PPP units to build government capacity, enhance market visibility and transparency, develop robust project pipelines, and standardize PPP procurement practices (Casady and Geddes 2016). However, the way countries experience PPP institutionalization largely depends on how these quasi-governmental agencies are structured and utilized at various levels of government. Mrak (2014) points out that PPP institutionalization generally follows three basic models-centralized, decentralized, or mixed.

In the first case, when PPP institutionalization is strongly centralized, "the entire institutional organization of the country or region for PPP is focused on one specialized institution" (Mrak 2014, 96). Conversely, when countries adopt a strongly decentralized approach to PPP institutionalization, no central PPP unit exists to support and coordinate PPP project preparation and execution. In this decentralized model, responsibility for PPP projects is left to state agencies, line ministries, or other local/municipal authorities. Unsurprisingly, the mixed model of PPP institutionalization integrates the previous two models. As the most frequently used form of PPP institutional organization, this mixed approach often has (1) a central/national PPP unit, (2) sectoral PPP agencies, and (3) other supporting institutions working together within a broader PPPenabling field (Jooste et al. 2012; Mrak 2014). Taken together, our case analysis utilizes these conceptual models in order to classify the type of PPP institutionalization unfolding in the United States.

\section{Data Sources}

Finally, in a theory-building, case-based research design, it is recommended that the selected methods align with the purpose of the case analysis (Eisenhardt and Graebner 2007). Because the institutionalization process of PPPs in the United States is currently not well documented, our analytical approach and application of institutionalization theory to this case remains exploratory. To conduct our exploratory analysis, we analyzed data on 368 U.S. PPP projects from

Table 1: Variable Definitions

\begin{tabular}{|c|c|c|c|}
\hline \multicolumn{2}{|c|}{ Development Type } & \multicolumn{2}{|c|}{ Sector } \\
\hline & $\begin{array}{l}\text { Greenfield: } \text { Construction of a piece of } \\
\text { infrastructure which did not } \\
\text { previously exist }\end{array}$ & 1) & $\begin{array}{l}\text { Transport: roads, rail, airports, ports, light rail, } \\
\text { carparks, bridges and tunnels, rolling stock }\end{array}$ \\
\hline 2) & $\begin{array}{l}\text { Brownfield: Trade of a part or whole } \\
\text { of an existing asset, which may } \\
\text { include obligation to improve or }\end{array}$ & & $\begin{array}{l}\text { Social Infrasrtucture: healthcare, schools, } \\
\text { prisons, defense, social housing, } \\
\text { accommodation, street lighting, leisure }\end{array}$ \\
\hline & expand existing facilities & & \multirow{3}{*}{$\begin{array}{l}\text { Environmental: water, waste } \\
\text { Renewable Energy: solar PV and CSP, onshore } \\
\text { and offshore wind, biomass, hydro, geothermal, } \\
\text { tidal, wave and project portfolios, electricity } \\
\text { storage }\end{array}$} \\
\hline \multicolumn{2}{|c|}{ Procurement Stage } & & \\
\hline & $\begin{array}{l}\text { Pre-launch: Grantor is contemplating } \\
\text { an asset tender }\end{array}$ & & \\
\hline 2) & $\begin{array}{l}\text { In procurement: Time period from } \\
\text { the formal or informal launch of a } \\
\text { tender unitl financial close }\end{array}$ & 5) & $\begin{array}{l}\text { Power: energy generation, energy transmission, } \\
\text { oil and gas storage }\end{array}$ \\
\hline 3) & $\begin{array}{l}\text { Financial close: The preferred bidder } \\
\text { secures financing and completes all } \\
\text { regulatory processes }\end{array}$ & & $\begin{array}{l}\text { Telecommunications: fixed line, wireless } \\
\text { transmission, data centers }\end{array}$ \\
\hline
\end{tabular}


Inframation's global transactions database. ${ }^{3}$ This data contains project information across state/local jurisdictions on grantors, transaction sizes, development types (i.e. greenfield or brownfield), sectors, contractual models (e.g. DBFOM), and procurement stages (pre-launch to financial close). ${ }^{4}$ The development types, procurement stages, and sectors examined in this analysis are defined in Table 1.

Table 2 breaks down the project data by development type, procurement stage, and sector.

In addition to the project data, we also reviewed archival records directly pertaining to the U.S. PPP market, such as academic manuscripts, government reports, news articles, commercial databases, and print/online sources (see, e.g. Iseki et al. 2009; Garvin 2010; Geddes 2011; Geddes and Wagner 2013; Albalate, Bel, and Geddes 2015; Surowiecki 2016; Albalate, Bel, and Geddes 2017; Bennon, Kim, and Levitt 2017; Geddes and Reeves 2017; Buckberg, Mudge, and Sheffield 2018). Using these quantitative and qualitative sources, we then applied the aforementioned theories of PPP institutionalization to the U.S. PPP market.

By developing existing theory through observation, analysis, and explanation of the U.S. case, our methodology offers "a richness of understanding" which "compensate[s] for weaknesses in traditional [research] approaches" (Perry 2012, 480). However, this research does have its limitaions. For examle, we cannot benchmark the US case against international PPP experience because we purposefully did not set thresholds for the stages of PPP institutionalization in this paper. We did this for a number of reasons. First, as an exploratory analysis, we wanted to let the data indictate where changes in the stages emerged. Second, we did not want to project international PPP experiences on to the U.S. because not all countries are expected to follow the same institutionalization curve or length of stages. We also felt it was unreasonable to expect the scale of PPP programs to conform to a uniform set of thresholds. Additioanlly, because time and space

Table 2: PPP Projects By Development Type, Procuement Stage, and Sector

\begin{tabular}{|c|c|c|c|c|c|}
\hline \multicolumn{3}{|l|}{ Development Type } & \multicolumn{3}{|l|}{ Procurement Stage } \\
\hline Greenfield & 357 & $97 \%$ & Transport & 191 & $52 \%$ \\
\hline Brownfield & 11 & $3 \%$ & Social Infrastructure & 93 & $25 \%$ \\
\hline Total & 368 & $100 \%$ & Environment & 43 & $12 \%$ \\
\hline \multicolumn{3}{|l|}{ Sector } & \multirow{4}{*}{$\begin{array}{l}\text { Power } \\
\text { Other } \\
\text { Telecommunications } \\
\text { Renewables }\end{array}$} & 11 & $3 \%$ \\
\hline Pre-Launch & 136 & $37 \%$ & & 5 & $1 \%$ \\
\hline In Procurement & 128 & $35 \%$ & & 18 & $5 \%$ \\
\hline Financial Close & 67 & $18 \%$ & & 7 & $2 \%$ \\
\hline \multirow{2}{*}{$\begin{array}{l}\text { On Hold } \\
\text { Cancelled }\end{array}$} & 11 & $3 \%$ & \multirow[t]{3}{*}{$\overline{\text { Total }}$} & \multirow[t]{3}{*}{368} & \multirow[t]{3}{*}{$100 \%$} \\
\hline & 26 & $7 \%$ & & & \\
\hline Total & 368 & $100 \%$ & & & \\
\hline
\end{tabular}

3 This count reflects PPP project status as of August 31, 2018. Projects that were refinancing, without private financing, or private-to-private transactions were excluded from this analysis.
4 The data in the Inframation's database is collected by a devoted team of journalists who review PPP contracts/documents and conducte interviews with public and private setor stakeholders in the market. 
requirements preclude us from providing a detailed historical account of PPP institutionalization across every U.S. state and territory, the scope of this research was also limited to analyzing the U.S. PPP market as a single, holistic case. While case studies can contain nested units or embedded subcases within the main unit of analysis (Yin 2017), we did not attempt to assess PPP institutionalization at specific state and local jurisdictions. Moreover, because this paper focuses narrowly on PPP institutionalization, we cannot not possibly do justice to all of the broader institutional processes and experiences affecting the totality of America's infrastructure stock. Despite these limitations, this research remains the first of its kind to systematically examine the process of PPP institutionalization. In the next section, we begin our case analysis of PPP institutionalization in the U.S.

\section{Case Analysis: PPP Institutionalization in the United States}

\section{Barriers to Innovation}

Although PPPs are not necessarily "new," they, like other innovations, arose primarily in "response to structural conditions ... that create[d] strategic interests or contingent events for actors in local contexts" (Johnson et al. 2006, 60). Examples of these structural conditions include endemic project cost overruns, schedule delays, and deferred maintenance. Many countries around the world have increasingly turned to PPPs to address these pervasive issues in infrastructure service delivery. In doing so, they have been forced to navigate challenging institutional dynamics involved in PPP governance, settings which can either enable or constrain the development of effective PPP programs (Henisz et al. 2012, Delhi and Mahalingam 2017). While leading PPP jurisdictions like Canada, Australia, and the United Kingdom have established "mature systems of government regulation as well as [normalized] market rules" to address these governance challenges, weak institutions and scarce institutional capacity in other nations, specifically the United States, have made PPP institutionalization especially challenging (Wang, $\mathrm{Wu}$, and Zhu 2018, 296).

The United States has been particularly slow to adopt PPPs as an innovative procurement model (Garvin 2010). Today, only 67 projects have reached financial close across the United States, totalling roughly $\$ 53$ billion in investments (see Figure 3).

Following the first PPP procurements in the early 1990s, the United States experienced little to no PPP activity for a little more than a decade. Only within the last ten years have PPPs started to gain some traction. This gradualism in PPP adoption has been widely attributed to historically rooted, institutional barriers in the U.S. market (Geddes 2011; Bennon, Kim, and Levitt 2017). For example, since the end of World War II, construction of nationally significant infrastructure - e.g. the Interstate Highway Program, Clean Water Program, Urban Mass Transportation Agency's (UMTA) $)^{5}$ transit program - has traditionally been funded using $90 \%$ federal funds and $10 \%$ local funds. At the same time, states and municipalities tasked with the funding of ongoing operations and maintenance of these projects have tended to defer maintenance expenditures indefinitely until the federal government steps in to fund the rehabilitation or replacement of deteriorating infrastructure assets (Kirk and Mallett 2013; Bennon, Kim, and Levitt 2017). This historical bifurcation of infrastructure investment priorities between federal, state, and municipal governments has created an unbalanced funding model which dis-incentivizes private investment in U.S. infrastructure. Moreover, the underlying fragmentation of infrastructure provision responsibilities across different levels of government undermine any sort of harmonization between the U.S. PPP program, the budget, and its public procurement system (Mrak 2014; Albalate,

5 The Urban Mass Transportation Agency (UMTA) became the Federal Transit Administration (FTA) in 1991.

The Engineering Project Organization Journal

(C)2017 Engineering Project Organization Society www.epossociety.org 
Figure 3: PPPs Reaching Financial Close in the United States (1992 - 2018)

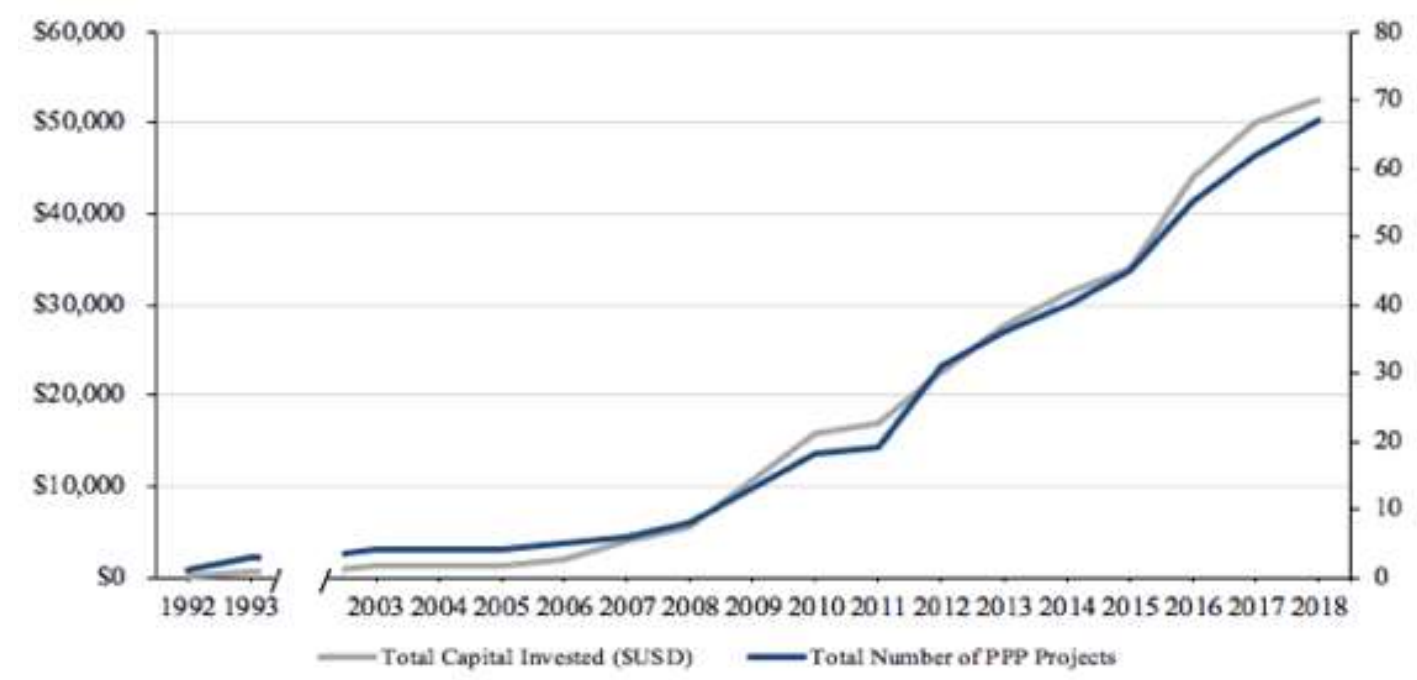

Notes: Because there was little to no PPP activity in the U.S. from 1993 - 2003, these years were not included for illustrative purposes.

Bel, and Geddes 2015; Bennon, Kim, and Levitt 2017).

Election cycles and the unique, tax-exempt municipal bond market in the United States accentuate this misalignment in federal, state, and local investment priorities by creating political incentives which favor new infrastructure projects and public borrowing over adequate maintenance of existing infrastructure assets and private financing. It is not uncommon for politicians to favor launching new infrastructure projects rather than spending taxpayer dollars on maintaining existing assets (Surowiecki 2016), nor is it politically attractive for public agencies to pass up the cost of capital advantages associated with municipal bond financing. ${ }^{6}$ Taken together, these institutional barriers have significantly tilted the playing field away from PPPs and in favour of the government financing, operating and maintaining - albeit under-maintaining-U.S. infrastructure projects (Bennon, Kim, and Levitt 2017).

6 Tax-exemption on municipal bonds does not really reduce the cost of public borrowing. Government are simply forgoing taxes they could otherwise collect.

\section{Local Validation: A Decentralized Process}

As a result, local validation of PPPs in the U.S. has been relatively decentralized. Because the U.S. lacks a central PPP unit to support and coordinate PPP project preparation and execution, responsibility for PPP projects has largely been left to state agencies and other local/municipal authorities. As a result, wide variation in PPP utilization, execution, and governance exists across state lines, within specific infrastructure sectors, and amongst cities as well as some metropolitan transit agencies. The absence of clear PPP policy guidelines, cohesive project prioritization frameworks, uniform procurement procedures, and standardized contracts has created an unstable policy environment devoid of the technical capacity, regulator autonomy, decision-making predictability, and process transparency found in more mature PPP markets (Garvin 2010; Bennon, Kim, and Levitt 2017). Although some states and municipalities have established PPP-enabling 
Figure 4: PPP Procurements in U.S. (Node Size $=$ Total Private Capital Attracted)

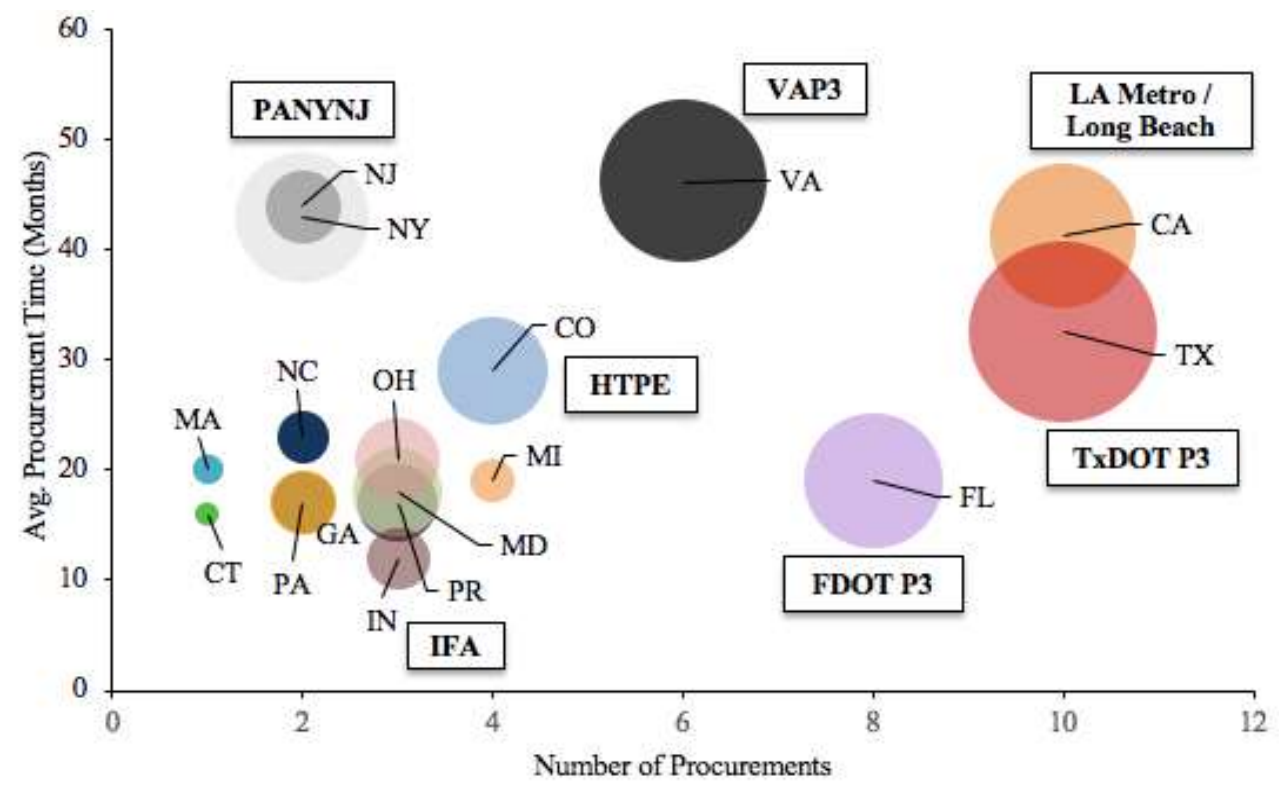

organizations or units to help governments navigate the complexities of PPP proceedings with greater consistency, transparency, and legitimacy, these entities differ significantly in their institutional organization and scope of responsibilities. While some states conduct their PPP programs directly through the state's department of transportation (e.g. Florida and Texas), others utilize more specialized entities or offices to steward their PPP programs (e.g. Virginia, Indiana, Colorado, California, and Washington, DC). Consequentially, states across the U.S. have experienced variable PPP tendering durations and a relatively uneven distribution of PPP procurements (see Figure 4).

This local validation of the PPP model in a handful of states is not surprising. Higher PPP adoption has generally occurred in more populated states where larger markets exist for potential users or customers (Albalate, Bel, and Geddes 2015). For instance, only California and Texas have delivered ten PPP projects while many others have yet to complete a single procurement. ${ }^{7}$ Moreover, in America's unique institutional setting, characterized by divergent national and regional priorities and dissimilar infrastructure processes, states attempting to deliver experience and build confidence in their PPP procurement capacity have only been able to procure a handful of "pathfinder" projects (Bennon, Kim, and Levitt 2017).

\section{Diffusion: America's Current Phase of PPP Institutionalization}

Despite these institutional barriers, the use of PPP projects in the United States continues to grow. Increasing PPP activity is largely being driven by the ongoing economic, political, and social consequences of America's enormous infrastructure deficit (Buckberg, Mudge, and Sheffield 2018). For instance, local jurisdiction debt-stress and tax burdens are forcing governments toward enhanced private involvement in infrastructure contracting (Bel and Fageda 2009; Albalate, Bel and Geddes 2015; Boyer and Scheller 2017). Moreover, increasing healthcare and pension obligations, declining discretionary

7 Within the last year, both Texas (TxDOT) and California (Caltrans) lost their transportation PPP authorization. 
Figure 5: PPP Enabling Legislation

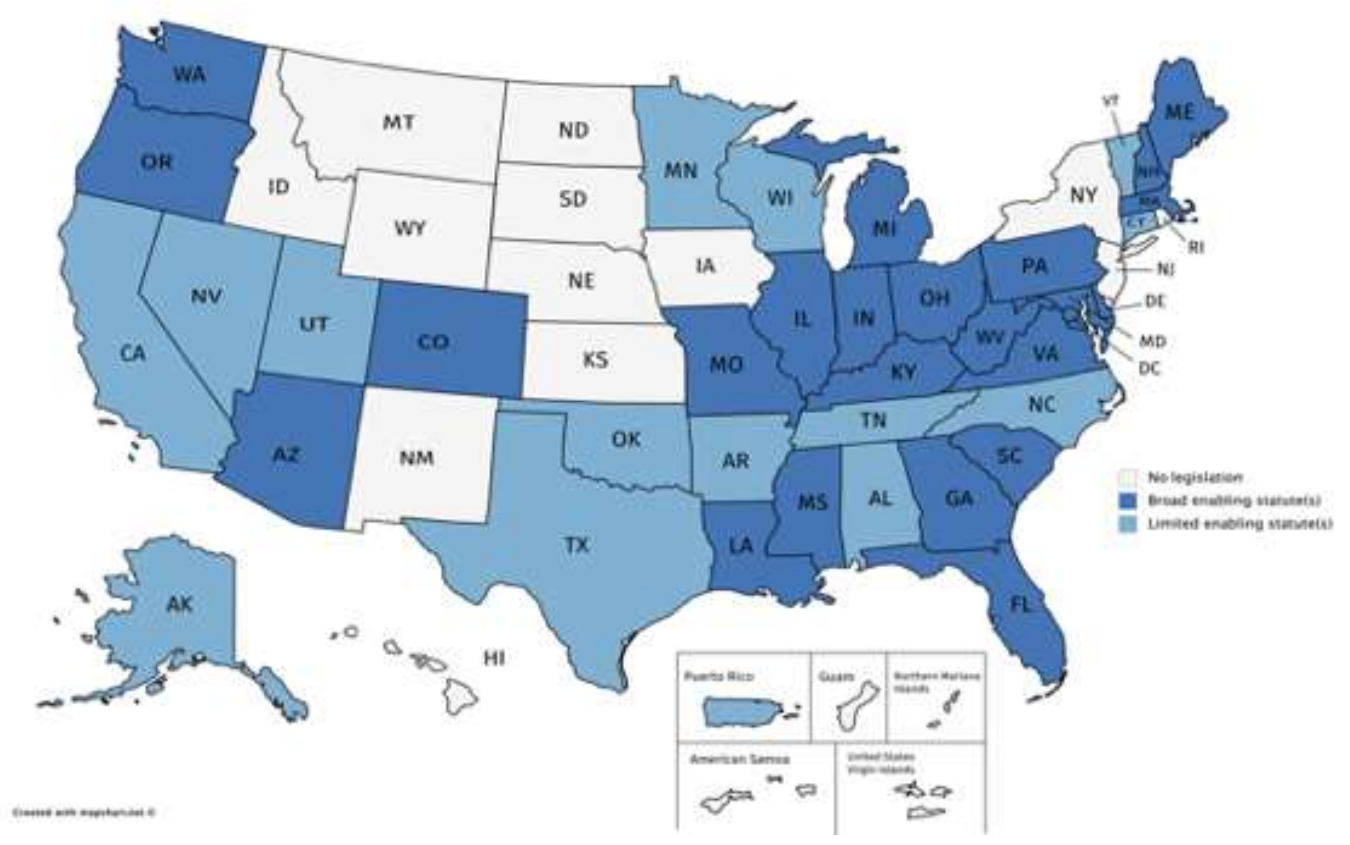

Figure 6: PPP Institutionalization in the United States (1992 - 2018)

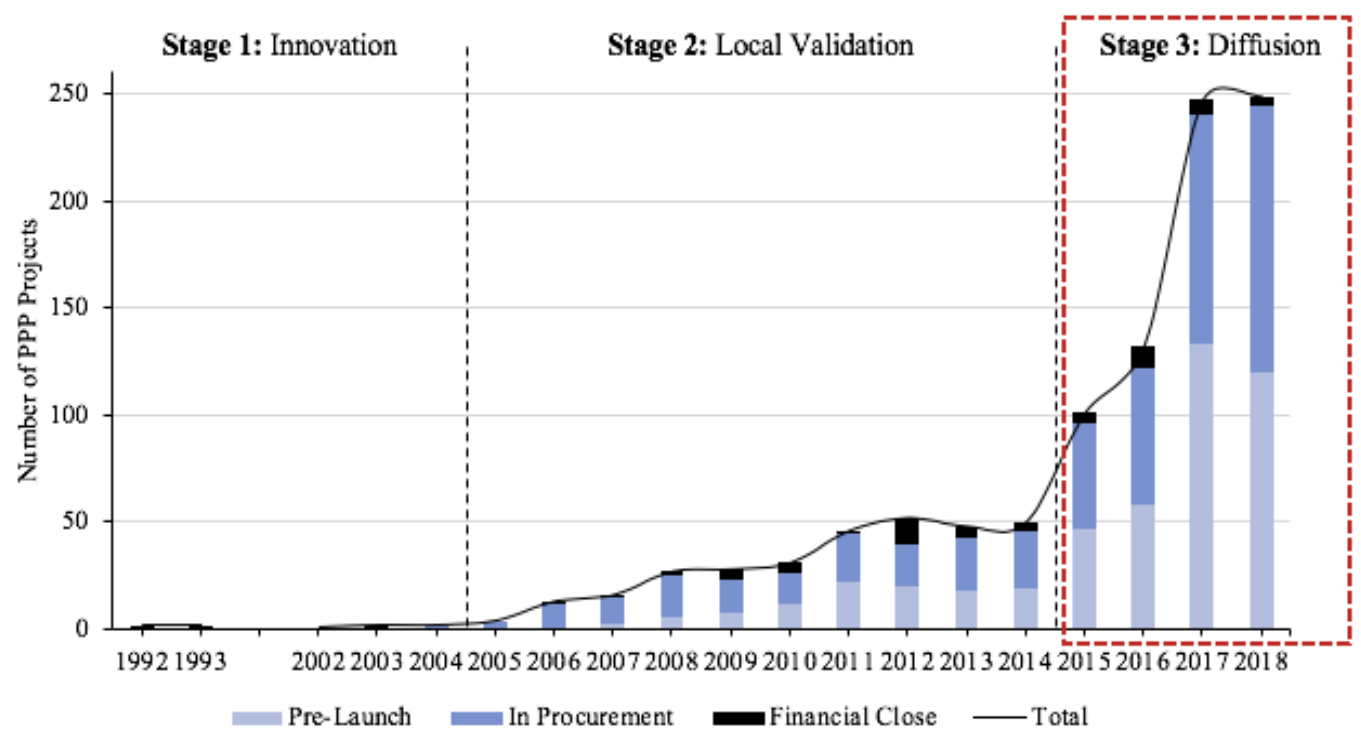

Notes: Project counts reflect the year-end project status. This excludes projects that were classified as cancelled, on hold, without private financing, private-to-private transactions, or refinancing. Because there was little to no PPP activity in the U.S. from 1993 - 2003, these years were not included for illustrative purposes. 
budgets, and growing public opposition to tax increases are exacerbating declines in federal, state, and local funding for infrastructure investment (Cawley 2013; DeCorla-Souza, Lee, Timothy, and Mayer 2013; Engel, Fischer, and Galetovic 2014). Taken together, these challenging structural conditions have made the adoption of PPPs "a pragmatic rather than a political decision" (Albalate, Bel, and Geddes 2017, 41).

To accommodate this growing pragmatism, the United States has experienced a proliferation of general administrative law, sector regulations, and specifically stipulated PPP contract provisions (Queiroz and Lopez 2013). As of August 2018, 37 states, the District of Columbia, and one U.S. territory have enacted PPP statutes (see Figure 5).

While the adoption and favorability of PPPenabling laws has typically followed local demand side, supply side, and political/institutional drivers such as state debt and urban travel demand (Geddes and Wagner 2013; Albalate, Bel, and Geddes 2017; Boyer and Scheller 2017) rather than traditional public finance considerations, such as federal highway aid (Geddes and Wagner 2013), the implementation of these statutes has not been consistent. Wide spread variation currently exists between state-level, PPP-enabling environments. Depending on how the institutional framework surrounding PPP procurement is structured, these statutes can either provide a supportive environment for PPP procurement or undermine PPP activity. Overall, difficulties associated with balancing contractual flexibility and public-interest protections have created large dipartites in PPP favorability between states (Geddes and Reeves 2017; Iseki et al. 2009). Yet, even with these challenges, a growing body of procurement law and jurisprudence is emerging across the U.S. as the PPP market matures.

Naturally, the slow development and maturation of PPP-enabling institutions, legal frameworks, and governance structures is having an effect on America's PPP institutionalization process. Figure 6 depicts the progression of PPP institutionalization in the United States as "a

\footnotetext{
8 These findings generally conform with the three-stage PPP market maturity curve conceived by Eggers and Startup (2006).
}

contested process that unfolds across time" (Johnson et al. 2006, 59). ${ }^{8}$

After years of limited PPP use during the innovation and local validation phases of institutionalization, the pipeline of U.S. PPP projects has grown rapidly in recent years. Since 2015, 36 states plus Puerto Rico and the District of Columbia has launched or closed at least one PPP transaction (see Figure 7).

Many of these states now pursuing PPPs have also "[come] up with their own plans for raising additional transportation revenue - while hoping the federal government continues their historic role as a strong partner in their efforts" (Transport for America 2018). Since 2012, 31 states have approved legislation to raise additional transportation revenue (see Figure 8).

As a result, the prominenace of transporation PPPs has waned in recent years. ${ }^{9}$ As PPPs have diffused across the US, the pipeline of projects has become more diverse (see Figure 9).

Prior to $2015,83 \%$ of all U.S. PPPs were concentrated in the transportation sector. Today, transportation accounts for only $45 \%$ of the overall total while social infrastructure and environmental PPPs now make up $29 \%$ and $13 \%$ of the project pipeline respectively. These developments indicate the U.S. PPP market is maturing. However, America's decentralized diffusion process has yet to produce a growth pattern reflecting widespread acceptance of the PPP model. Inconsistent PPP procurement procedures, dissimilar legal and regulatory environments across state lines, and minimal use of PPP-enabling organizations (e.g. PPP units) continue to create instability in the market. Although the number of projects has skyrocketed in recent years, the U.S. is still experiencing a high rate of project cancellations. Currently, for every six projects that reach financial close, one PPP project is cancelled. Additionally, there are a handful of projects in the pipeline which remain on hold with no timetable for completion.

These ongoing institutional challenges within America's fractured federalism have led many private firms and public agencies to believe that current U.S. institutions (e.g. laws, rules, social

9 If transportation funding is available through traditional procurement, the incentive for governments to pursue transport PPPs is diminished. 
Figure 7: PPPs Since 2015, By State

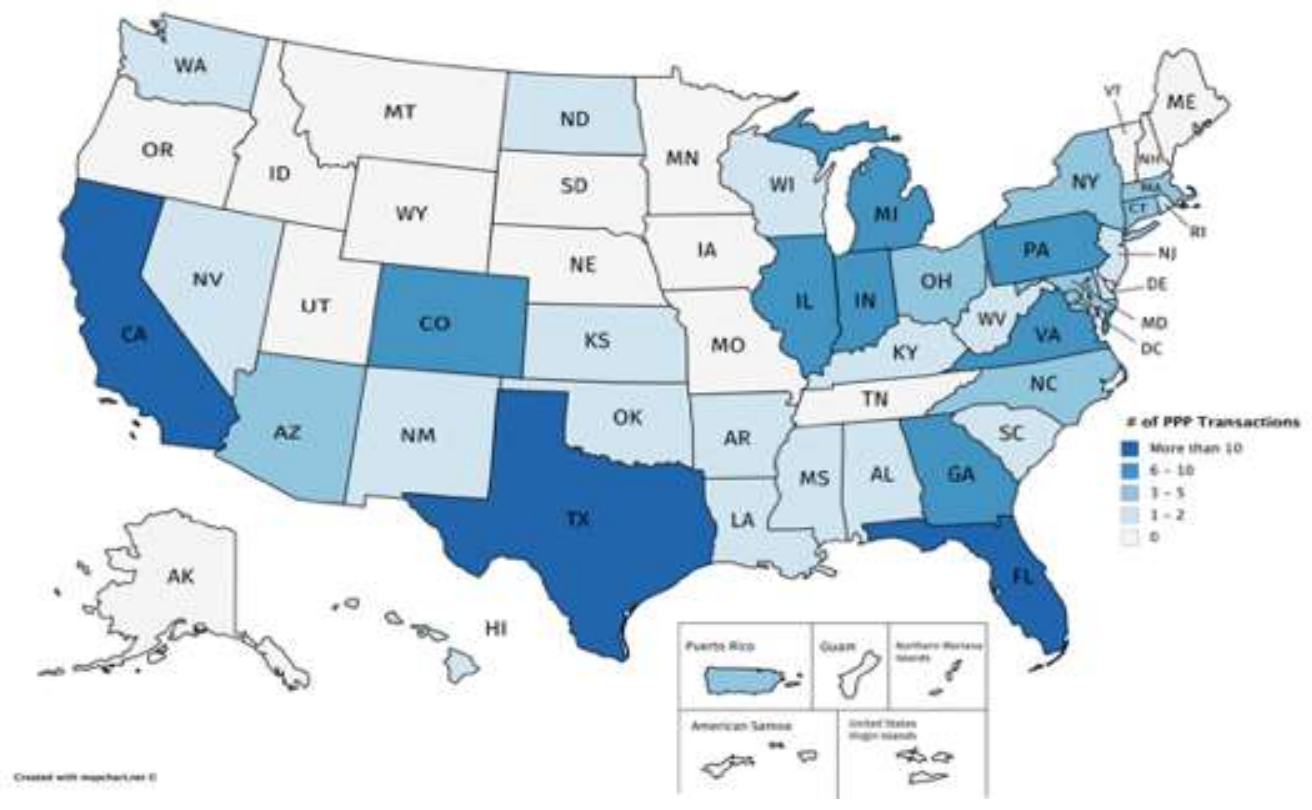

Notes: Including projects that have reached financial close or are in procurement. Excludes pre-launch projects.

Figure 8: Transportation Funding Legislation Since 2015, By State

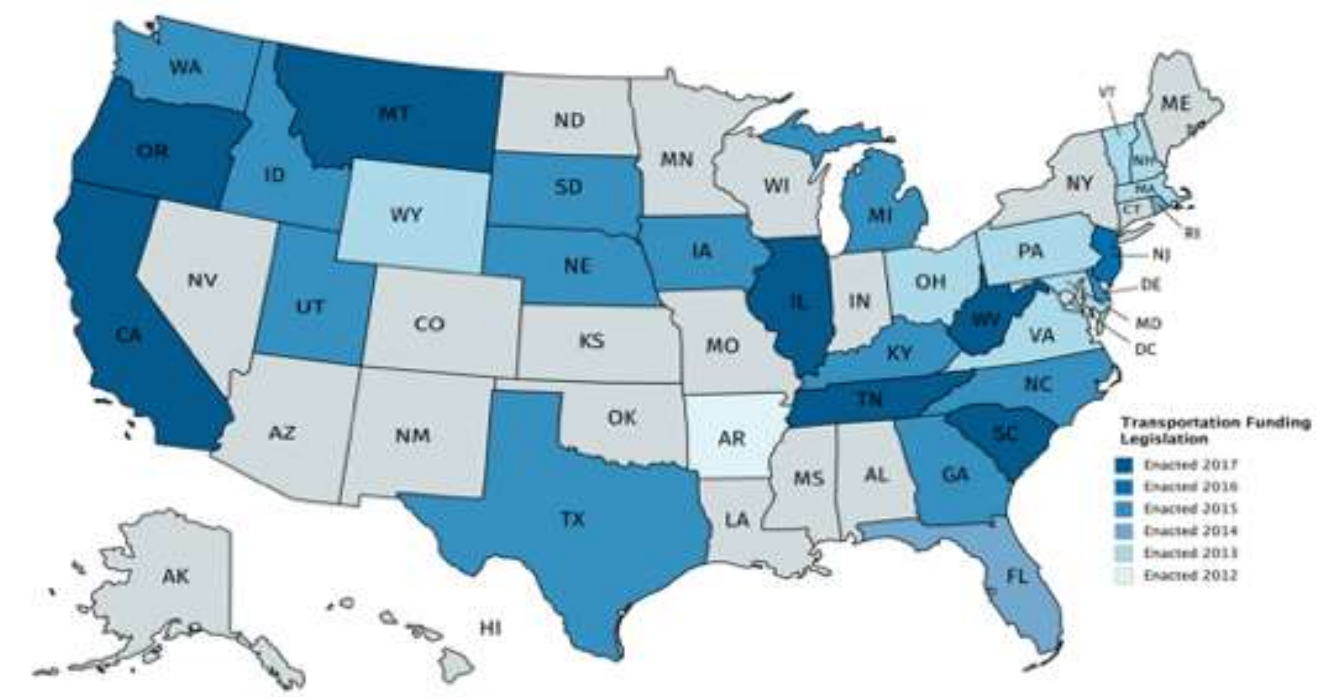


norms, and policy) do not offer enough incentives, transparency, and accountability for the U.S. to successfully deliver a coordinated PPP program (Geddes and Reeves 2017). If the U.S. is going to adhere to the natural progression of the institutionalization process and generally validate the PPP model, then more U.S. public agencies at the federal, state, and municipal level will need to improve their governance capacities, address existing knowledge gaps, share and adopt best practices, and "reform institutions or build new organizations to assess and manage new models for infrastructure procurement and assets management" (Bennon, Kim, and Levitt 2017, 24; Boyer 2016).

\section{Achieving General Validation Through a Mixed PPP Institutionalization Model}

Although the U.S. PPP market is currently in a state of decentralized diffusion, it still, in many ways, remains "at earlier stages of PPP development and could benefit from the opportunity to learn from the trailblazers who have moved to more advanced stages" (Eggers and Startup 2006, 6). Among mature markets which have generally validated the PPP model, the most frequently used form of PPP institutional organization is the mixed model, consisting of (1) a central/national PPP unit, (2) sectoral PPP agencies, and (3) other enabling institutions. The U.S. could readily move from a strongly decentralized PPP institutionalization model to a mixed approach by "establish[ing] clear, predictable and legitimate institutional framework[s] supported by competent and well-

Figure 9: PPP Projects By Sector

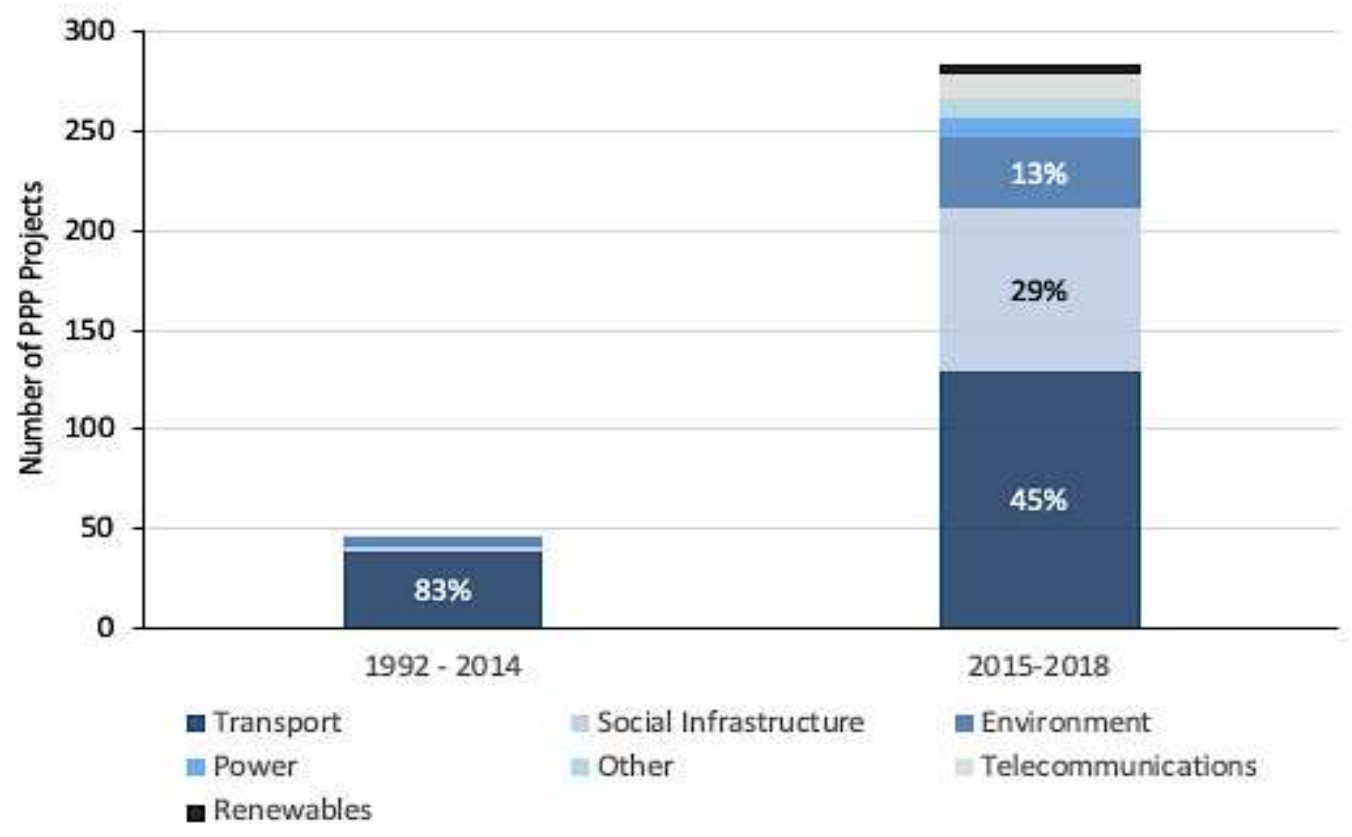

Notes: Includes projects that are pre-launch, in procurement, or have reached financial close. 
resourced authorities" (World Bank \& DFID 2009; OECD 2012, 8). ${ }^{10}$

In recent years, efforts have begun at the federal level to centralize PPP knowledge, procurement guidelines, and expertise as legislative measures and supporting federal institutions have become increasing favorable toward PPP procurement (Iseki et al. 2009). ${ }^{11}$ Most of these efforts have occurred in the transportation sector which holds the largest share of U.S. PPPs. For example, in May 2018, the Federal Transit Administration (FTA) issued a Final Rule on Private Investment Project Procedures (PIPP) which:

establishe[d] procedures that allow recipients of FTA funds to identify perceived impediments to the use of public-private partnerships (P3s) and private investment in public transportation capital projects either proposed or under construction and in the Statewide LongRange Transportation Plan or the Metropolitan Transportation Plan, and seek a waiver or modification of such impediments" (FTA 2018).

Additionally, within the US Department of Transportation, entire offices are now dedicated to promoting PPPs as an alternative infrastructure delivery mechanism. For example, the Federal Highway Administration's (FHWA) Office of Innovative Program Delivery (OIPD) offers technical guidance and public-sector capacity support for innovative financing and project management arrangements such as PPPs. Likewise, the passage of the Fixing America's Surface Transportation (FAST) Act in 2015 led to the creation of the Build America Bureau, an entity designed to "[serve] as the single point of contact and coordination for states, municipalities and project sponsors looking to utilize federal transportation expertise, apply for federal transportation credit programs and explore ways to access private capital in public private partnerships" (Build America Bureau 2017). Operating under the Office of the Undersecretary

10 For a more detailed review of PPP governance mechanisms, see World Bank and DFID (2009) as well as OECD (2012). for Transportation Policy, this nascent bureau replaced the Build America Transportation Investment Center (BATIC) and assumed responsibility for streamlining access to credit and grant opportunities as well as encouraging the adoption of best practices in project development, delivery, financing, and management. Some of the Bureau's core responsibilities include:

(1) Centralized project coordination, projectlevel technical assistance, and alternative project delivery assessment;

(2) Federal credit enhancement via Transportation Infrastructure Finance and Innovation Act (TIFIA) and Railroad Rehabilitation and Improvement Financing (RRIF) direct loans, loan guarantees, and standby lines of credit;

(3) Management of the tax-exempt Private Activity Bonds (PABs) program for prospective PPP concessionaires; and

(4) Administration of Infrastructure For Rebuilding America (INFRA) grants for critical projects on US highways and bridges (Build America Bureau 2017).

Together, federal institutions like the Bureau and OIPD are working to address ongoing institutional barriers in the U.S. market which affect PPP adoption and utilization. However, their role within a mixed model of PPP institutionalization should not be overstated. Because infrastructure provision happens primarily at the state and local level, "developments at the federal level are often limited in scope and effect and typically provide only general guidelines for PPP implementation" (Geddes and Reeves 2017, 159). This is particularly true in other sectors outside of transportation where private activity is stronger (e.g. energy, social infrastructure, etc.) and the need for any centralized federal support at the agency level is minimal.

\footnotetext{
${ }^{11}$ See Iseki et al. (2009) for a detailed assessment of PPP-enabling federal legislation.
} 
strategies that could be enacted in a given institutional environment for successful outcomes." In general, however, the U.S. has a unique opportunity to accelerate its PPP institutionalization process by closing the knowledge gap, adopting domestic and international best practices, and establishing credible governance processes supported by a mature, enabling institutional environment.

\section{Conclusions}

(3) More consistent PPP legislation and procurement procedures across levels of government;

(4) Transparent infrastructure project prioritization using non-partisan, expert panels; and

(5) The adoption and utilization of PPP units at the regional and national level.

These general reforms are common in more mature PPP markets, and the "US can capitalize on the tested experience of its international counterparts" to implement them (Garvin 2010, 402). By doing so, the U.S. may be able to avoid setbacks in the institutionalization process and "move up the PPP maturity curve more rapidly and leapfrog to more advanced stages of maturity" (Eggers and Startup 2006, 6).

However, careful consideration must always be given to the transferability of PPP international best practices (Acerete, Gasca, Stafford, and Stapleton 2015). This is especially true at the state and local level where more research is needed on the localized development of PPP-enabling institutions (Boardman, Greve, and Hodge 2015; see also Van den Hurk et al. 2015). Additionally, successful validation of the PPP approach in the United States will require further work on comprehensive performance metrics for PPPs as well as objective criteria for a multi-level assessment of PPP institutionalization across state and local US jurisdictions. In this regard, the framework recently developed by Delhi an Mahalingam (2017, 115) may be useful for "understand[ing] the minimum set of governance
Public sector institutions facing vague, competing, and dynamic policy objectives are increasingly using PPPs to overcome shortcomings in traditional infrastructure project delivery. Although traditional infrastructure procurement methods offer governments, in most projects, the ability to "[internalize] transactions, [minimize] legalisms involved in complex contractual negotiations with external actors, and [provide] a more stable framework for bargaining" (Salamon 2002, 31), many governments globally have turned to PPPs in order to break the government monopoly on infrastructure development, inject competition and flexibility into infrastructure contracting, improve infrastructure service quality, and enhance the public sector's technical, financial, and physical capacity to deliver projects. PPPs also offer some attractive potential benefits such as ontime and within-budget delivery, life cycle asset maintenance, design innovation, and enhanced access to private capital.

However, PPP projects in the US and around the world also present governments with a unique governance task. These alternative procurement mechanisms contain embedded challenges across many stages of the project lifecycle. High transaction costs, long procurement timelines, budgetary problems, and lost government flexibility are just some of issues that can arise from PPP contracting. Moreover, the planning, execution, and management of these projects institutional setting. While some researchers have begun to "systematically develop a comprehensive typology of institutional conditions and project specific strategies" which promote satisfactory market development and PPP project performance becomes especially challenging without a mature 
(Delhi an Mahalingam 2017, 131), the process of PPP institutionalization has garnered relatively little attention. Our research addresses this gap in the literature in the following ways. First, we use a combination of extant institutionalization theories to define the phases and types of PPP institutionalization. Next, we use the U.S. PPP market as test case to explore the descriptive power institutionalization can serve as a powerful tool for examining market development, isolating PPP governance shortcomings, and identifying areas of institutional reform.

Moving forward, we are interested in using Inframation's data on 5,607 PPP projects across Africa, Asia, Australasia, Europe, Latin America, North America, and the Middle East to test whether

Figure 10: Alternative Institutionalization Dynamics

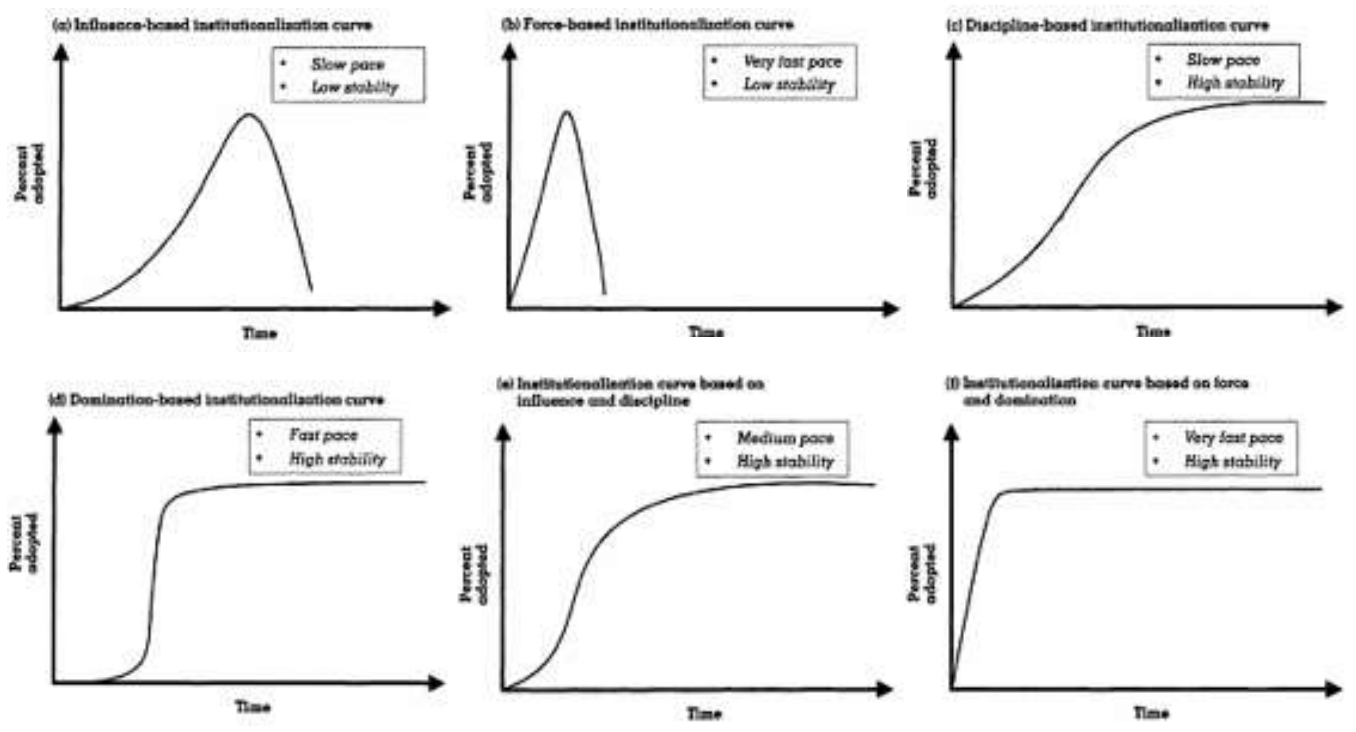

of these criteria for PPP market development. Finally, this paper reinforces the critical role institutional settings play in the successful planning, execution, and enforcement of PPPs contracts. By applying Mrak's (2014) and Johnson et al.'s (2006) institutionalization frameworks to the U.S. PPP market, our review: (1) identifies America's current stage in the PPP institutionalization process; (2) classifies the type of PPP institutionalization unfolding in the U.S., and (3) highlights various institutional deficiencies across the United States that require further development and reform. While some scholars might argue that one cannot generalize from a single case, ${ }^{12}$ our examination of the U.S. PPP market shows that analyses of PPP

12 See Flyvbjerg (2006) for a detailed treatment of common misunderstandings associated with case study research. patterns of PPP institutionalization conform to the alternative institutionalization curves outlined in Lawrence, Winn, and Jennings (2001) (see Figure $10)$.

However, this is just one line of inquiry. Other scholars should also expand on the initial insights of this paper by exploring PPP institutionalization temporal dynamics in other countries. Moreover, future research should aim to further explicate the PPP institutionalization process, map changing institutional dynamics overtime, and develop key metrics of PPP market maturity. 


\section{References}

Acerete, Basilio, Mar Gasca, Anne Stafford, and Pamela Stapleton. 2015. "A comparative policy analysis of healthcare PPPs: Examining evidence from two Spanish regions from an international perspective." Journal of Comparative Policy Analysis: Research and Practice.

Albalate, Daniel, Germà Bel, and R. Richard Geddes. 2015. "The determinants of contractual choice for private involvement in infrastructure projects." Public Money \& Management 35, no. 1: 87-94.

Albalate, Daniel, Germà Bel, and R. Richard Geddes. 2017. "How Much Vertical Integration? Contractual Choice and Public-Private Partnerships in the United States." Review of Industrial Organization: 25-42.

Bel, Germà, and Xavier Fageda. 2009. "ㅍactors explaining local privatization: a meta-regression analysis." Public Choice 139, no. 1: 105-119.

Bennett, John, and Elisabetta Iossa. 2006. "Building and managing facilities for public services." Journal of public economics 90, no. 10: 2143-2160.

Bennon, Mike, Kim, M. Julie, and Raymond E. Levitt. (2017). U.S. Infrastructure Gap(s): Federal Policy and Local Public Institutions. [Internet]. In Press.

Bingham, Lisa Blomgren, and Rosemary O'Leary. 2014. Big ideas in collaborative public management. Routledge.

Boardman, Anthony E., Carsten Greve, and Graeme A. Hodge. 2015. "Comparative Analyses of Infrastructure Public-Private Partnerships." Journal of Comparative Policy Analysis: Research and Practice 17, no. 5: 441-447.

Bovaird, Tony. 2004. "Public-Private Partnerships: From Contested Concepts to Prevalent Practice." International Review of Administrative Sciences 70, no. 2: 199-215.

Boyer, Eric J. 2016. "Identifying a Knowledge Management Approach for Public-Private Partnerships." Public Performance \& Management Review 40, no. 1: 158-180.

Boyer, Eric J., and Daniel S. Scheller. 2017. "An Examination of State-Level Public-Private Partnership Adoption: Analyzing Economic, Political, and Demand-Related Determinants of PPPs." Public Works Management \& Policy: $1087724 X 17729097$.

Buckberg, Elaine, Mudge, Robtert, and Hannah Sheffield. 2018. "Rising Tide of Next Generation U.S. P3s - and How to Sustain It." The Brattle Group.

Build America Bureau. 2017. "About the Build America Bureau." US Department of Transportation. Accessed November 21, 2017. https://www.transportation.gov/buildamerica/about
Burger, Philippe, and Ian Hawkesworth. 2011. "How to attain value for money: comparing PPP and traditional infrastructure public procurement." OECD Journal on Budgeting 11, no. 1: 91.

Buxbaum, Jeffrey N., and Iris N. Ortiz. 2007. Protecting the public interest: The role of long-term concession agreements for providing transportation infrastructure. No. 07-02. Keston Institute for Public Finance Policy and Infrastructure Policy, University of Southern California.

Casady, Carter B. and R. Richard Geddes. 2016. "Private Participation in US Infrastructure: The Role of PPP Units." Washington, DC: American Enterprise Institute (AEI).

Cawley, Kim P. 2013. Testimony on the Status of the Highway Trust Fund. No. 44434. Congressional Budget Office.

Chou, Jui-Sheng, and Dinar Pramudawardhani. 2015. "Cross-country comparisons of key drivers, critical success factors and risk allocation for public-private partnership projects." International Journal of Project Management 33, no. 5: 1136-1150.

DeCorla-Souza, Patrick, Douglass Lee, Darren Timothy, and Jennifer Mayer. 2013. "Comparing public-private partnerships with conventional procurement: incorporating considerations from benefit-cost analysis." Transportation Research Record: Journal of the Transportation Research Board 2346: 32-39.

Delhi, Venkata SK, Seshanka Palukuri, and Ashwin Mahalingam. 2010. “Governance Issues in Public Private Partnerships in Infrastructure Projects in India." Paper presented at the Engineering Project Organizations Conference, South Lake Tahoe, CA.

Delhi, Venkata Santosh Kumar, and Ashwin Mahalingam. 2017. "Factors influencing the postaward governance of PPP projects: A proposed framework." Engineering Project Organization Journal 7, no.2 : 114-134

DiMaggio, Paul, and Walter W. Powell. 1983. "The iron cage revisited: Collective rationality and institutional isomorphism in organizational fields." American Sociological Review 48, no. 2: 147-160.

Eisenhardt, Kathleen M., and Melissa E. Graebner. 2007. "Theory Building from Cases: Opportunities and Challenges." Academy of Management Journal 50, no.1: 25-32.

Engel, Eduardo, Ronald D. Fischer, and Alexander Galetovic. 2014. The Economics of Public-Private Partnerships: A Basic Guide. Cambridge: Cambridge University Press.

Eggers, William D., and Tom Startup. 2006. Closing the Infrastructure Gap: The Role of Public-Private Partnerships. Deloitte Research Study: Deloitte. 
The Engineering Project Organization Journal (December 2018) Volume 8

European PPP Expertise Centre (EPEC). 2014."Establishing and Reforming PPP Units: Analysis of EPEC Member PPP Units and Lessons Learnt." Washington, DC: World Bank Group.

Farquharson, Edward, Clemencia Torres de Mastle, E. R. Yescombe, and Javier Encinas. 2011. How to Engage with the Private Sector in Public-Private Partnerships in Emerging Markets. Washington, DC: World Bank.

Federal Highway Administration (FHWA). 2018. " $\underline{\text { State }}$ P3 Legislation." Washington, DC: U.S. Department of Transportation, Center for Innovative Finance Support.

Federal Transit Adminstration (FTA). 2018. What are Private Investment Project Procedures (PIPP)? U.S. Department of Transportation (USDOT).

Flyvbjerg, Bent. 2006. "Five misunderstandings about case-study research." Qualitative Inquiry 12, no. 2: 219-245.

Forrer, John, James Edwin Kee, Kathryn E. Newcomer, and Eric Boyer. 2007. "Public-Private Partnerships and the Public Accountability Question." Public Administration Review, 70, no. 3: 475-484

Garvin, Michael J. 2010. "Enabling development of the transportation public-private partnership market in the United States." Journal of Construction Engineering and Management 136, no. 4: 402-411.

Geddes, R. Richard. 2011. The Road to Renewal: Private Investment in United States Transportation Infrastructure. Washington, DC: American Enterprise Institute (AEI) Press.

Geddes, R. Richard and Benjamin L. Wagner. 2013. "Why do U.S. States Adopt Public-Private Partnership Enabling Legislation?" Journal of Urban Economics, 78: 30-41.

Geddes, R. Richard, and Eoin Reeves. 2017. "The Favourability of US PPP Enabling Legislation and Private Investment in Transportation Infrastructure." Utilities Policy 48: 157-165.

Greve, Carsten, and Graeme Hodge. 2010. "Publicprivate partnerships and public governance challenges." In New Public Governance?, pp. 149162. Routledge.

Grimsey, Darrin, and Mervyn Lewis. 2007. Public Private Partnerships: The Worldwide Revolution in Infrastructure Provision and Project Finance. Edward Elgar Publishing.

Guasch, J. Luis, Jean-Jacques Laffont, and Stephane Straub. 2008. "Renegotiation of concession contracts in Latin America: Evidence from the water and transport sectors." International Journal of Industrial Organization 26, no. 2: 421-442.

Hall, Daniel M., and W. Richard Scott 2018. "Early stages in the institutionalization of Integrated Project Delivery, Engineering Project Organization Journal.
Hellowell, Mark, and Veronica Vecchi. 2015. "The Non-Incremental Road to Disaster? A Comparative Policy Analysis of Agency Problems in the Commissioning of Infrastructure Projects in the UK and Italy." Journal of Comparative Policy Analysis: Research and Practice 17, no. 5: 519-532.

Henisz, Witold J., Raymond E. Levitt, and W. Richard Scott. 2012. "Toward a unified theory of project governance: economic, sociological and psychological supports for relational contracting." Engineering Project Organization Journal 2, no. 1-2: 37-55.

HM Treasury. 2012. A New Approach to Public Private Partnerships. London: HM Treasury.

Hodge, Graeme A., and Carsten Greve, eds. 2005. The challenge of public-private partnerships: Learning from international experience. Edward Elgar Publishing.

Hodge, Graeme A., and Carsten Greve. 2007. "PublicPrivate Partnerships: An International Performance Review." Public Administration Review, 67, no. 3: 545-558.

Hodge, Graeme A., Carsten Greve, and Anthony Boardman, eds. 2010. International Handbook of Public-Private Partnerships. Cheltenham: Edward Elgar Publishing.

Hodge, Graeme A. 2013. "Keynote presentation to Global Challenges in PPP: Cross-Sectoral and CrossDisciplinary Solutions?", 6-7 November 2013, Universiteit Antwerpen, City Campus, Hof Van Liere.

Inframation. 2018. "Global Transactions Database." Accessed August 31, 2018.

Iossa, Elisabetta, and David Martimort. 2015. "The Simple Microeconomics of Public-Private Partnerships." Journal of Public Economic Theory, 17, no. 1: 4-48.

Iseki, Hiroyuki, Jeanette Eckert, Kansai Uchida, Ryan Dunn, and Brian Deane Taylor. 2009. Task B-2: Status of legislative settings to facilitate public private partnerships in the US. California PATH Program, Institute of Transportation Studies, University of California at Berkeley.

Istrate, Emilia, and Puentes, Robert. 2011. "Moving forward on public private partnerships: US and international experience with PPP units." Washington, DC; Brookings Institution.

Johnson, Cathryn, Timothy J. Dowd, and Cecilia L. Ridgeway. 2006. "Legitimacy as a social process." Annual Review of Sociology 32: 53-78.

Jooste, Stephen F., Raymond E. Levitt, and W. Richard Scott. 2011. "Beyond 'one size fits all': How local conditions shape PPP enabling field development." Engineering Project Organization Journal, 1, no.1: 11-25. 
Jooste, Stephen F., and W. Richard Scott. 2012. "The public-private partnership enabling field: evidence from three cases." Administration \& Society 44, no. 2: 149-182.

Kettl, Donald. F. 1993. "Sharing Power." Washington, DC: Brookings Institution.

Kettl, Donald F. 2011. Sharing Power: Public Governance and Private Markets. Brookings Institution Press.

Kinder, Tony. 2012. "Learning, innovating and performance in post-new public management of locally delivered public services." Public Management Review 14, no. 3: 403-428.

Kirk, Robert S., and William J. Mallett. 2013. "Highway bridge conditions: Issues for Congress." Rep. No. R43103.

KPMG. 2010. "Procurement, Review of Barriers to Competition and Efficiency in the Procurement of PPP Projects." KPMG Corporate Finance (aust) Pty Ltd.

Kwak, Young Hoon, YingYi Chih, and C. William Ibbs. 2009. "Towards a comprehensive understanding of public private partnerships for infrastructure development." California Management Rreview 51, no. 2: 51-78.

Lammam, Charles, Hugh MacIntyre, and Joseph Berechman. 2013. "Using public-private partnerships to improve transportation infrastructure in Canada." Vancouver: Fraser Institute.

Lawrence, Thomas B., Monika I. Winn, and P. Devereaux Jennings. 2001. "The temporal dynamics of institutionalization." Academy of management review 26, no. 4: 624-644.

Mahalingam Ashwin. 2010. "PPP experiences in Indian cities: barriers, enablers, and the way forward." Journal of Construction Engineering and Management 136, no. 4: 419-29.

Martimort, David. And Jerome Pouyet. 2008. "To build or not to build: Normative and positive theories of public-private partnerships." International Journal of Industrial Organization 26, no.2: 393-411.

Martin, Lawrence, Wendell Lawther, Graeme Hodge, and Carsten Greve. 2013. "Internationally recommended best practices in transportation financing public-private partnerships (P3s)." Public Administration Research 2, no. 2: 15.

Marsilio, Marta, Giulia Cappellaro, and Corrado Cuccurullo. "The intellectual structure of research into PPPS: A bibliometric analysis." Public Management Review 13, no. 6 (2011): 763-782.

Matos-Castaño, Julieta, Ashwin Mahalingam, and Geert Dewulf. 2014. "Unpacking the Path-Dependent Process of Institutional Change for PPPs." Australian journal of public administration 73, no. 1: 47-66.
McNichol, Dan. 2013. "The United States: The World's Largest Emerging P3 Market." Star America Infrastructure Fund and AIG.

Meyer, John W., and Brian Rowan. 1977. "Institutionalized organizations: Formal structure as myth and ceremony." American journal of sociology 83 , no. 2: 340-363.

Mrak, Mojmir. 2014. "Institutionalization of PublicPrivate Partnership: Global Experiences and the Basic Outlines of a Proposal for Slovenia." Central European Public Administration Review 4, no. 1: 91103.

Moulton, Lynne, and Helmut K. Anheier. 2002. "Publicprivate partnerships in the United States: Historical patterns and current trends." In Public-Private Partnerships: Theory and Practice in International Perspective, edited by Stephen Osborne. Routledge.

OECD. 2012. "Recommendation of the Council on Principles for Public Governance of Public-Private Partnerships." Organization for Economic Cooperation \& Development (OECD).

Opara, Michael, Fathi Elloumi, Oliver Okafor, and Hussein Warsame. 2017. "Effects of the Institutional Environment on Public-Private Partnership (P3) Projects: Evidence from Canada." Accounting Forum 41, no. 2: 77-95.

Perry, James L. 2012. "How can we improve our science to generate more usable knowledge for public professionals?." Public Administration Review 72, no. 4: 479-482.

Petersen, Ole Helby. 2011. "Public-private partnerships as converging or diverging trends in public management? A comparative analysis of PPP policy and regulation in Denmark and Ireland." International Public Management Review 12, no. 2: 1-37.

Queiroz, Cesar, and Alejandro Lopez Martinez. 2013. "Legal frameworks for successful public-private partnerships." In The Routledge Companion to Public-Private Partnerships, edited by Piet De Vries and Etienne B. Yehoue, 75-94. Routledge.

Raisbeck, Peter, Colin Duffield, and Ming Xu. 2010. "Comparative performance of PPPs and traditional procurement in Australia." Construction Management and Economics 28, no. 4: 345-359.

Reeves, Eoin, Dónal Palcic, Darragh Flannery, and R. Richard Geddes. 2017. "The determinants of tendering periods for PPP procurement in the UK: an empirical analysis." Applied Economics 49, no. 11: 1071-1082.

Ross, Thomas W., and Jing Yan. 2015. "Comparing public-private partnerships and traditional public procurement: Efficiency vs. flexibility." Journal of Comparative Policy Analysis: Research and Practice 17, no. 5: 448-466. 
Salamon, Lester M., and Odus V. Elliott. 2002. The tools of government: A guide to the new governance. Oxford University Press.

Scott, W. Richard, and John W. Meyer. 1994. Institutional environments and organizations: Structural complexity and individualism. Sage.

Siemiatycki, Matti. 2013. "Is there a distinctive Canadian PPP Model? Reflections on Twenty Years of Practice." Paper presented at the Second CBSSauder-Monash PPP Conference, Vancouver, BC, 13-14 June.

Soecipto, Raden Murwantara, and Koen Verhoest. 2018. "Contract stability in European road infrastructure PPPs: how does governmental PPP support contribute to preventing contract renegotiation?." Public Management Review: 1-20.

South, Andrew J., Raymond E. Levitt, and G. P. M. R. Dewulf. 2015. "Dynamic stakeholder networks and the governance of PPPs." In Proceedings of the $2 n d$ International Conference on Public-Private Partnerships.

Suchman, Mark C. 1995a. "Localism and globalism in institutional analysis." In The Institutional Construction of Organizations: International and Longitudinal Studies, edited by W. Richard Scott and Soren Christensen, 39-63. Sage.

Suchman, Mark C. 1995b. "Managing legitimacy: Strategic and institutional approaches." Academy of Management Review 20, no. 3: 571-610.

Surowiecki, James. 2016, April 18. "System Overload." The New Yorker.

Transport for America. 2018. State Transportation Funding: The states successfully raising new transportation revenue. Washington, DC: Transport for America

Van den Hurk, Martijn, Lena Brogaard, Veiko Lember, Ole Helby Petersen, and Petr Witz. 2015. "National varieties of Public-Private Partnerships (PPPs): A comparative analysis of PPP-supporting units in 19 European countries." Journal of Comparative Policy Analysis: Research and Practice 18, no. 1: 1-20.

Verhoest, Koen, Ole Helby Petersen, Walter Scherrer, and Raden Murwantara Soecipto. 2015. "How do governments support the development of public private partnerships? Measuring and comparing PPP governmental support in 20 European countries." Transport Reviews 35, no. 2: 118-139.

Verhoest, Koen, Nunzia Carbonara, Veiko Lember, Ole Helby Petersen, Walter Scherrer, and Martijn Van den Hurk. 2013. "Public Private Partnerships in Transport: Trends \& Theory P3T3." Discussion Papers part I, COST.

Wang, Huanming, Wei Xiong, Guangdong Wu, and Dajian Zhu. 2018. "Public-private partnership in Public Administration discipline: a literature review." Public Management Review 20, no. 2: 293316

Wettenhall, Roger. 2003. "The rhetoric and reality of public-private partnerships." Public Organization Review 3, no. 1: 77-107.

Wettenhall, Roger. 2005. "The Public-Private Interface: Surveying the History." In The Challenge of PublicPrivate Partnerships: Learning from International Experience, edited by Graeme Hodge and Carsten Greve, 22-43. Cheltenham, UK: Edward Elgar.

Wibowo, Andreas, and Hans Wilhelm Alfen. 2015. "Government-led critical success factors in PPP infrastructure development." Built Environment Project and Asset Management 5, no. 1: 121-134.

World Bank. 2007. "Public-Private Partnership Units: Lessons for their Design and Use in Infrastructure." Washington, DC: World Bank.

World Bank. 2017. "Public Private Partnerships Reference Guide: Version 3." Washington, DC: International Bank for Reconstruction and Development/World Bank.

World Bank and DFID. 2009. "Good Governance In Public-Private Partnerships: A Resource Guide for Practitioners." The World Bank \& Department for International Development of the United Kingdom (DFID).

Yang, Yongheng, Yilin Hou, and Youqiang Wang. 2013. "On the development of public-private partnerships in transitional economies: An explanatory framework." Public Administration Review 73, no. 2: 301-310.

Yescombe, Edward R. 2011. Public-private partnerships: principles of policy and finance. Butterworth-Heinemann.

Yin, Robert K. 2017. Case Study Research and Applications: Design and Methods. Sage Publications.

Zucker, Lynne G. 1987. "Institutional theories of organization." Annual review of sociology 13, no. 1: 443-464.

The Engineering Project Organization Journal

(C)2017 Engineering Project Organization Society www.epossociety.org 